\title{
Ekonomi Media: Perlukah?
}

\author{
Bakir Hasan
}

\author{
ABSTRACT
}

\begin{abstract}
Rapid development of communication technology has shaped a new cultural landscape. In effect, the nature of mass media industry also changed a lot. To anticipate this new development, communication discipline needs a new study focused on media economy. Media economy is combination of two perspectives in media studies: business-economy perspective and media communication perspectives. The dimension of media in media economy emphasized three areas: production, content, and audiences. The dimension of economy in media economy studies focused on structure, conduct/policy, and performance. Meanwhile, the management of media corporation are consisted of revenue, cost and profit dimensions.
\end{abstract}

Kata kunci: ekonomi media, perspektif bisnis media, perspektif kajian media

Mengelola perusahaan media dewasa ini, apakah itu media cetak, radio atau televisi, tidak sama dengan mengelola perusahaan yang sama pada masa-masa lalu. Keterbukaan pasar pers sejak era reformasi dan pengaruh keterbukaan pasar Indonesia terhadap persaingan dari luar atau globalisasi membawa dampak yang besar pada pasar media di negara kita.

Era perjuangan yang dikenal dalam industri media kita sudah menjadi sejarah masa lalu. Era yang berjalan sejak zaman kolonialisme itu, telah berubah sejak perekonomian Indonesia mengalami kemajuan-kemajuan di masa pemerintahan Soeharto. Industi media tidak lagi tergantung pada subsidi partai atau pemerintah. Pada saat itu, industri media mulai memasuki masa baru yang disebut dengan era bisnis dalam media, di mana periklanan telah menjadi sumber penting penghasilan industri media dan persaingan di pasar bertambah sengit dalam rangka merebut kue iklan.

Pada saat itu, industri media tidak lagi menjual atau memasarkan produk content-nya kepada pasar khalayak, tetapi juga menjual produk audiencenya kepada dunia usaha sebagai pengiklan (advertisers), di mana pasar periklanan meningkat dan persaingan media untuk merebut kue iklan itu juga meningkat.

\section{Cabang Baru Ilmu Komunikasi: Ekonomi Media (Media Economics) ${ }^{1}$}

Ilmu baru di bidang komunikasi ini merupakan penggabungan kajian media dan kajian ekonomi. Walaupun baru tumbuh sejak 1970-an, ilmu ini telah menunjukkan kemajuan pesat. Bukan hanya berbagai buku teks bagi para mahasiswa dan 
dosen di negara maju tentang ekonomi media telah lahir, seperti yang ditulis A.B. Albarran, Robert $G$. Picad, Colin Hoskins bersama Stuart McFadyen dan Adam Finn dan Alison dan Alsion Alexander dengan James Owers dan Rod Carveth, tetapi juga majalah jurnal ilmiah yang terbit telah menunjukkan mantapnya disiplin ilmu baru ini, seperti Journal of Media Economics, Journal of Business Media Studies, dan Journal of International Media Management, yang telah terbit sejak 1980.

\section{Mengapa Diperlukan Kajian Baru Ini?}

Ekonomi media sebenarnya tumbuh bersamaan dengan tumbuhnya industri media dan perekonomian pada umumnya. Pada awal abad 20, kajian media masih menggunakan hanya perspektif komunikasi, karena memang kajian media merupakan salah satu wilayah kajian komunikasi. Tiga perspektif dimensi komunikasi yang dijadikan bidang kajian adalah: (1) dimensi produksi, (2) dimensi content, dan (3) dimensi audiences. ${ }^{2}$

Pada masa itu memang perusahaan media masih dianggap sebagai institusi sosial. Artinya, perusahaan media tidak dianggap sebagai perusahaan yang komersial atau lembaga yang mencari laba. Yang dicari oleh para entrepreneur media pada masa itu adalah prestise, power, serta pengaruh karena medianya yang banyak dibaca oleh khalayak (audience). Penerimaan atau income kecil dari usahanya mengelola media tidak terlalu merisaukannya. Bahkan pada masa itu, kehidupan media masih tergantung pada bantuan dan subsidi pemerintah atau partai politik. Ini banyak terjadi di Amerika Serikat pada awal pertumbuhan media.

Di Indonesia, pada zaman kolonial dua media pers sudah bisa hidup dengan subur dari dukungan iklan dunia usaha: media pers milik Belanda dan media pers milik Tionghoa. Kedua media pers ini tergolong media yang mendukung status quo atau dengan kata lain, mereka mendukung pemerintahan kolonial Belanda.

Di lain pihak, media pers nasionalis yang miskin dari dukungan dunia usaha (dan memang dunia usaha nasional atau pribumi pada waktu itu jumlahnya tidak berarti) harus hidup kembang kempis, meskipun semangat juangnya mendukung perjuangan untuk merdeka sangat tinggi. Sebagai akibatnya, media pers nasional ini sering menderita dari tindakan pembredelan dari penguasa. Sampai era Bung Karno, media pers masih dianggap sebagai institusi sosial denggan semangat juangnya, tetapi sekarang dalam konteks perjuangan partai pendukungnya masing-masing. Hal itu dapat dilihat dari bentuk hukum perusahaan media pada era itu, yaitu Yayasan yang pada dasar nya bersifat nirlaba (non-profit). Baru setelah masa pemerintahan Soeharto, di mana ketentuan SIUPP (business licence) diberlakukan, bentuk hukum yg harus dipakai adalah PT atau Perseroan Terbatas, di mana laba menjadi motivasi pendirian perusahaan media.

Walaupun pada awal abad 20 media pers di AS masih dianggap sebagai institusi sosial, tetapi setelah Perang Dunia II (1939-1945), perusahaan media sudah mulai menunjukkan ciri komersialnya. Ini tentu ada sebabnya, khususnya karena adanya perubahan lingkungan ekonominya. Pada masa itu, mesin industri yang selama itu dipergunakan untuk perang, mulai kembali dipergunakan untuk menghasilkan produksi untuk memenuhi kebutuhan masyarakat. Dunia industri yang telah memasuki pasar memerlukan media promosi yang hanya dapat dilakukan oleh perusahaan media, baik media cetak, radio maupun televisi, yang muncul setelah era perang itu.

Sejak itu, perusahaan media tidak lagi hanya menerima pendapatan dari para pelanggan, tapi juga dari penerimaan iklan dunia usaha. Dalam perkembangan selanjutnya penerimaan iklan, bahkan jauh melebihi penerimaan dari langganan. Pada media pers seperti surat kabar penerimaan dari iklan mencapai $70-80 \%$ dari total income. Pada radio dan televisi, di mana pemirsa atau pendengar tidak dipungut biaya, maka pemasukan iklan merupakan satu-satunya income atau 100\%. Dari sini kelihatan bahwa media tidak bisa lagi dianggap sebagai institusi sosial. Media telah menjadi perusahaan bisnis sebagaimana perusahaan lainnya, di mana profit atau laba menjadi motivasi dasarnya. Media juga harus bersaing dipasar, baik dalam merebut pasar con- 
tent-nya maupun pasar audience-nya.

Dalam keadaan perusahaan media yang tumbuh inilah muncul minat dari ekonom dan sarjana bisnis untuk melakukan kajian tentang media dengan perspektif ekonomi. ${ }^{3}$ Ini terjadi diberbagai kampus di Amerika Serikat dan di Eropa. Di samping mulai munculnya buku-buku teks tentang ekonomi media, munculnya jurnal-jurnal ekonomi media dan manajemen, menjelang akhir abad 20 terjadi berbagai gejala konsentrasi dan integrasi dalam industri media, yang menjadikan bidang kajian ekonomi pada industri media lebih menantang, khususnya karena adanya kekhawatiran hal itu akan mengancam proses demokratisasi dalam masyarakat, karena timbulnya gejala monopoli informasi dalam masyarakat.

\section{Apa itu Ekonomi Media?}

Ekonomi media adalah gabungan dua kajian: kajian media dengan perspektif komunikasi dan kajian media dengan perspektif ekonomi dan bisnis. Dengan kata lain, ekonomi media tidak lain adalah penggunaan peralatan analisis ekonomi (economic tools of analysis) pada perusahaan media. Kalau dalam kajian media dengan perspektif komunikasi terdapat 3 dimensi (1) produksi, (2) content, dan (3) audience, maka dalam kajian ekonomi, terdapat 3 dimensi, yakni (1) dimensi structure, (2) dimensi conduct atau kebijakan, dan (3) dimensi performance. ${ }^{4}$ Sedang pada tingkat pengelolaan perusahaan media, studi ekonomi media memiliki 3 dimensi : (1) dimensi revenue, (2) dimensi cost, dan (3) dimensi profit. ${ }^{5}$

Penelitian - penelitian di bidang ini untuk industri media Indonesia masih belum dimulai. Gambarannya masih gelap. Penelitian saya tahun 2005 dalam rangka disertasi doktoral hanya meliputi struktur pasar dan persaingan antara surat kabar. Salah satu kesulitan penelitian media ini adalah ketiadaan data sekunder dan sulitnya mendapat dukungan dari dunia media sendiri. Ada keengganan dari pihak manajemen media untuk membuka informasi tentang perusahaannya, apalagi informasi keuangannya. Kelemahan ketersediaan data dan informasi tentang media ini, antara lain, karena tidak adanya audit dari lembaga independent seperti yang berlaku pada industri media pers di negara lain. Lembaga yang dikenal dengan singkatan ABC (Audit Bureau of Circulation $)^{6}$ dirasakan kegunaannya oleh siapa pun, tapi sulit didirikan di Indonesia karena berbagai kepentingan yang berbeda dari perusahaan pers . Mungkin di sinilah perlunya campur tangan pemerintah sebagai pihak ketiga untuk mendirikan lembaga independen itu.

Karena di negara maju saja, ekonomi media sebagai ilmu, baru tumbuh pada dekade 1970-an, maka tidaklah terlalu terlambat bagi pada sarjana komunikasi dan sarjana ekonomi yang berminat pada sektor informasi yang strategis ini untuk memulai kajian ekonomi media ini di Indonesia.

\section{Mengapa Media Massa Berbeda dengan Industri Lainnya?}

Ada tiga hal membedakan industri media dengan industri lainnya: (1) Dalam industri media, peran iklan sangat dominan, (2) Media massa bagi masyarakat (warganegara) merupakan sumber informasi penting, (3) Berbeda dengan industri lainnya, industri media merupakan industri yang dilindungi oleh undang-undang dasar negara. (kebebasan bersuara). Di samping itu, yang membedakan industri media dengan industri lainnya adalah ciri-ciri ekonomisnya, seperti: (1) produk ganda (dual product), yakni: content product dan audience product, (2) pasar ganda (dual market) yakni: consumer market dan advertiser market, (3) industri media memiliki misi ganda (dual missions) yakni: economic mission dan noneconomic atau public mission. Ciri-ciri di atas cukup membuat masalah pengelolaan perusahaan media lebih rumit dari industri lainnya. Di atas ciriciri tersebut, industri media masih memiliki ciri yang khas melekat pada perilaku biayanya (cost behavior), seperti: (1) skala penghematan (economies of scale), (2) penghematan skop (economies of scope), penghematan integrasi (economies of integration).

Ketiga jenis penghematan ini dapat diraih industri media apabila jumlah produksinya besar, 
produknya bisa beraneka ragam dan bahkan bisa merupakan gabungan dari berbagai usaha. Karena ciri biaya ini, maka bertambah besar tiras surat kabar bertambah murah harga yang akan dibebankan pada konsumen; sedang di lain pihak, income dari periklanan akan meningkat, karena produk audience akan lebih menarik bagi para pengiklan (advertisers). Dimungkinkannya jumlah tiras untuk meningkat tentunya karena daya tarik mutu dari content koran itu.

Memang, kalau informasi merupakan business dari industri koran, maka content merupakan core business (usaha inti). Artinya, content adalah segala-galanya bagi mereka yang ingin mengelola koran dengan sukses. ${ }^{7}$ Hanya mereka yang menyadari akan hal ini akan berhasil dari bisnis korannya. Hal ini juga berlaku bagi media radio ataupun televisi. Kalau dalam bisnis retailing dikenal motto yang harus selalu diingat oleh mereka yang akan bergerak di bidang itu: location, location dan location (yang tidak lain artinya adalah menekankan pentingya peran lokasi bagi bisnis retailing), maka mungkin motto yang berbeda tapi dengan semangat yang sama bisa dikatakan dalam industri media: content, content dan content. Mungkin inilah kunci rahasia untuk menjawab mengapa banyak perusahaan koran yang tumbuh setelah datangnya era reformasi di negara kita malah justru bangkrut dan keluar dari pasar. Para pengusaha pers yang memasuki pasar pers era reformasi ini, yang konon jumlah mencapai ribuan pada umumnya adalah pemula dalam bisnis pers, sehingga seluk beluk pengelolaan pers belum dipahami benar, sehingga tanpa disadari produk koran yang dihasilkannya tidak menarik dan sebagai akibatnya tidak disukai oleh pembaca di pasar.

Hukum ini tidak hanya berlaku pada saat ini, tetapi akan selalu demikian, langgeng setiap masa. Siapa yang tidak memperhatikan aspek mutu content dari produk medianya akan digilas oleh persaingan di pasar. Di lain pihak, bertambah besar tiras suatu media pers bertambah besar incomenya dari iklan, bertambah sulit bagi media kecil lain untuk mengejarnya, kecuali yang kecil mampu secara kreatif menciptakan mutu content produk media yang mampu menarik pembaca dari bacaan lainnya. Sungguh suatu tantangan yang tidak mudah. Memang, mengelola industri media merupakan masalah yang kompleks dan karenanya memerlukan kejelian . Mungkin ekonomi media bisa menggambarkan dan memberikan solusi bagi berbagai masalah yang dihadapi dalam manajemen perusahaan media.

\section{Kesimpulan}

Industri media dewasa ini bukan lagi merupakan institusi sosial. Ia telah menjadi institusi bisnis . Dalam pengembangan industri media laba diperlukan sebagai imbalan bagi kesejahteraan pemilik modal, pemberi kredit, pimpinan perusahaan dan karyawan. Hanya dengan laba yang memadai, industri media dapat memperluas usahanya melalui usaha-usaha konsolidasi, konsentrasi, maupun konglomerasi. Mengelola industri media yang sudah besar itu tidak lagi dilakukan dengan caracara tradisional. Diperlukan peralatan analisa ekonomi (economic analysis) ${ }^{8}$ untuk memahami masalah ekonomi dalam perusahaan dan untuk keperluan pengambilan keputusan. Ekonomi media sebagai subdisiplin ilmu komunikasi yang baru mungkin bisa bermanfaat bagi pengembangan industri media dimanapun, termasuk di Indonesia. Juga, bagi para mahasiwa yang mau berkarier sebagai jurnalis maupun eksekutif di perusahaan media, dan industri media pada umumnya, media economics perlu juga dipelajari.

\section{Catatan Akhir}

Untuk buku teks pengantar Media Economics, baca A.B.Albarran (1996), Media Economics. Iowa State Univ. Press, Ames, Iowa

2 Untuk mendalami media process dengan pendekatan sosiologis, baca David Croteau \& William Hoyes (1997), MEDIA/ SOCIETY : Industries, Images and Audiences. A Sage Publication Company. London.

3 Pendekatan ekonomi untuk berbagai masalah "nonekonomi" memang sudah popular diberbagai kajian ilmu-ilmu sosial, karena adanya anggapan bahwa "economic approach is uniquely powerful because it can integrate a wide range of human behavior" (G.S.Becker, 1976). 
4 Untuk gambaran singkat tentang model IO (Industrial Organisation), baca Albarran (1996: p 29)

5 Untuk penjelasan tentang model bisnis ni, baca buku pengantar akuntansi.

6 Yang berminat pada teori dan praktek riset audience, baca Webster et al (2006), Rating Analysis. LEA, Publishers. Mahwah, New Jersey dan P.M. Napoli (2003), Audience Economics. Columbia Univ. Pres, New York.

7 Merupakan kelaziman dalam disiplin ekonomi/bisnis untuk bertanya, yang maksudnya adalah untuk memokuskan wilayah pasar dan kegiatan usahanya: What business, are you in? Selanjutnya: What is your core business? Fokus seperti dimaklumi adalah kunci dari daya saing perusahaan.

8 Yang sering dianggap sebagai key economic concepts adalah Scarcity, Choice, Opportunity Cost, Substitutes, Specialization, Trade, Incentives, and Economic Growth. (Colin Hoskins et al :p.15)

\section{Daftar Pustaka}

Paul Starr (?), The Creation of the Media. New York: Basics Books.

David Croteau \& William Hoynes. 1997. Media/ Society. Pine Forge Press. California: A Sage Publication Company.

Albarran, Olmsted, \& Wirth. 2006. Handbook of Media Management \& Economics. LEA, Inc, New Jersey.

John D.H. Downing, ChiefEditor. 2004. Sage Handbook of Media Studies. California: Sage Publication. 
